\title{
Some Reflections on Financial Fragility in Banking and Finance
}

\author{
Victoria Chick
}

The most valuable lesson I learned as a student of Hy Minsky's at Berkeley I learned after the seminars. Hy always had a good attendance at his Money and Banking seminars from the Bank of California and the San Francisco Fed, and we would all go to a local bierstube, where the beer came in vast pitchers and seemed in infinite supply. There I would watch fascinated as $\mathrm{Hy}$, who always dominated and steered the conversation, would turn first to a student, then to a banker, asking questions geared quite precisely to what each could reasonably be expected to know: theoretical questions to unworldly students and matters of practice and policy to the bankers. There seemed to be two entirely separate worlds of discourse-only $\mathrm{Hy}$ seemed able to live in both at once. It was all grist to his mill: in the next seminar, the answers to practical questions became part of the theoretical discourse, and theory would be turned to the analysis of some aspect of bank behavior we had heard about over beer. Despite all the pressures of the mainstream search for "pure" theory, Hy never departed from this method: the historical and institutional contingency of economic theory is a hallmark of Hy's work.

Like so much that I should have learned at the time, this lesson took time to come to some sort of fruition: I am by temperament a theorist, much less engaged with the world than $\mathrm{Hy}$, who was always deeply engaged. Eventually, the historical and institutional foundations of Keynes's General Theory began to intrigue me-and then a breakthrough came, when two big issues in economic theory came together: I realized that the reversal of causality between saving and investment was dependent on the banking system's having reached the stage at which it could create loans "by the stroke of the pen," independently of saving, because the resulting deposits had become means of payment and would be willingly held [Chick 1983]. It was this fa-

The author is Professor of Economics, University College London. This paper was presented at the annual meeting of the Association for Evolutionary Economics, New Orleans, Louisiana, January 46, 1997. 
cility that allowed the "long side of the market" (for saving and investment) to dominate when investment exceeded saving, and it was this new money that constituted the "injection into the circular flow of income" that we all told our first-year students about in those days.

Although banks had reached this stage [identified as "Stage 2" in Chick 1986] in England from round about the last quarter of the nineteenth century, and it can be argued that in Scotland the banks began in this phase because of a shortage of cash [Dow and Earl 1982, chap. 3; Chick and Dow 1997], the debate on the banks' power to create credit beyond the limits of intermediation was only settled in the 1920s [Crick 1927]. (Theory follows history with a long and variable lag.) Integration with the theory of autonomous expenditure waited for Keynes [1936], who did not make the link explicit. The role of bank credit in supporting investment has been part of the endogenous money story for a long time [see, e.g., Davidson 1972; 1979, chap. 11], but the story takes the ability of the banks to create credit independently of saving for granted rather than emphasizing the historical perspective: that perspective suggests that there was a time when the classical priority was true.

Having shown the importance of banking development to one of the most important conclusions of The General Theory, it is perhaps time to revisit the subject in the light of recent stages of the evolution of banking practice and to enquire whether these changes, in combination with modern techniques of company finance and changes in the securities markets, alter the conclusions of The General Theory regarding the role of investment. The changes in banking practice I have in mind are off-balance-sheet activities and, particularly, securitized lending [Stage 6 in Chick 1993]. These combine with the considerable reliance by firms of internal finance (which has been important at least since the end of World War II) and a recent shift toward the markets, rather than the banks, as sources of external finance. Finally, the major actors in securities markets are now pension funds and insurance companies: saving has become institutionalized and their management professionalized.

\section{The Finance and Funding of Investment}

In what I will refer to as the "Stage $2+$ " theory, because banks have reached their second stage of development or better, at least some of an expanded level of investment was first financed by bank lending, then later funded by firms issuing securities and paying the banks back. Finance takes place without prior saving; saving provides the funding. Funding fully restores the banks' liquidity. (Chick [1984], Davidson [1986], and Studart [1995] all argue that this picture derives from Keynes's post-General Theory writings in 1937-39, with the additional aspect of the evolutionary perspective on banking stressed by Chick and Studart.)

One conclusion of this analysis is that the pace of growth is important for the financial robustness of the system: while banks can finance a large amount of invest- 
ment, the resulting increase in the money supply will cause trouble if it is not continually resorbed by funding. While Keynesian saving is always "adequate," one must not forget that this aggregate includes holdings of new money generated in the financing of investment, and if these are in excess of desired holdings, inflation may result ${ }^{1}$ and the funding mechanism will be disturbed. The banks will become increasingly illiquid. This outcome is the likelier the faster the rate of growth of investment. So the robustness or fragility of the system is not only structural, but depends also on the pace of change [Chick 1984].

Toporowski [1994] has challenged this account of finance and funding. Quoting the famous passage, "When the capital development of a country becomes a byproduct of a casino, the job is likely to be ill-done" [Keynes 1936, 159], Toporowski comments, "Keynes was wrong on a matter of empirical fact: It is precisely because of these dangers that established companies try not to finance their fixed capital investment from the capital markets [but rather from] their reserves (i.e., their accumulated undistributed income) and in Britain some $80 \%$ of such investment is financed in this way" [1994, 70]. Internal financing by firms has long been emphasized by Post Keynesians, including Minsky [1975, chap. 5], who argued that firms will typically choose this method first because it is cheaper and the cost is less uncertain. And there is no doubt that today it is the dominant method. ${ }^{2}$ If it were the only method, however, the autonomy of investment would be in serious question.

Part of the problem is that the description is incomplete. Reserves are a bookkeeping entry. The matching entry is a collection of financial assets, mostly liquid. These will have to be sold to finance expenditure. From the point of view of the autonomy of investment, the effect is indistinguishable from financing by means of issue of new debt: the question is only who buys the debt or asset instruments. If they are purchased by banks in exchange for new deposits, the endogenous-money element of the story told above goes through. Firms will still have to arrange funding once the capital is on the balance sheet, but the liquidity of the purchasing banks does not rely on the success of this operation: the banks can restore their own liquidity when they wish by selling the asset.

If the assets are sold to the market, the story is the old loanable funds tale of new money being constrained by the flow of saving, unless there is some twist bringing in bank credit. One such twist arose in Britain in the 1980s, when the Bank of England acquired a significant amount of commercial paper, thus financing firms' expenditure with high-powered money. Another pertains to the U.S. market, where recent trends show that firms are going direct to market with commercial paper (which would later need funding) rather than to banks. However, the Federal Reserve, in response to the Penn Central default, now promises to support banks that back up commercial paper; commercial paper is thus routinely issued with a backup line of bank credit [Wray 1994, 29-30]. In this case, the new money remains po- 
tential, and unless and until lines of credit are activated, the transaction remains off the banks' balance sheets.

Both these examples concern short-term paper, usually associated with the finance of working capital rather than investment, but if the firm is building the new capital in-house, the two are indistinguishable. This point was just as pertinent to Keynes's explanation, for he would not have supposed that banks would lend for investment on a long-term basis either. This brings us to the role of the securities markets. Their funding role, as we have seen, needs to be supplemented by the provision of a market for assets when reserves need to be realized. The influence of the new actors (new, that is, in their importance since Keynes wrote) is one that Keynes anticipated:

It might have been supposed that competition between expert professionals, possessing judgment and knowledge beyond that of the average private investor, would correct the vagaries of the ignorant individual left to himself. It happens, however, that the energies and skill of the professional investor and speculator are mainly occupied . . . not with making superior long-term forecasts of the probable yield of an investment over its whole life, but with foreseeing changes in the conventional basis of valuation a short time ahead of the general public [Keynes 1936, 154].

The new actors in the casino are more active, the speculation more intense. With both the banks and firms turning to more securitized lending, the markets have a greater role in financing deficit expenditure as well as funding the capital stock, the influence of speculative behavior is increased.

\section{Financial Fragility in the Evolution of Banking}

An interesting question, perhaps, is why banks and firms are turning to securitized forms of finance. In my pieces on the evolution of banks [1986, 1993], it was the progressively enhanced freedom of banks to lend that took center stage, but the story is also a classic tale of the evolution of financial fragility. Drawing this point out, we see securitization and off-balance-sheet activity in clear perspective as retreats from the trend toward greater financial fragility.

Early in the story, when banks were isolated and (in England) drew their capital from no more than six partners with unlimited liability, both liquidity and solvency were primary concerns of the partners; they were sustained by prudent operations alone: wise loans and a good liquidity cushion were essential to long-term survival.

Gradually, banks formed links with London banks for both liquidity and operational reasons; these links allowed them access to the money markets in a liquidity crisis. (The U.S. equivalent is the correspondent link with Reserve City banks.) The discount houses served the purpose developed much later as direct interbank lending 
(U.S.: Federal Funds market). Now liquidity relied not only on each bank's operations but on system liquidity, the activities of the discount houses, and the behavior of the money market. By this time, the banks had been integrated by their willingness to accept each others' liabilities and conformed to the "banking system" of the textbook model, in which banks can expand their lending freely as long as others are acting in the same way, and since banks' liabilities are now acceptable as means of payment, the cash drain from lending was, for the system as a whole, also greatly reduced. The degree of prudence earlier required to maintain liquidity was thus greatly reduced, though banks had to learn the new limits by experience.

Some banks pushed their luck too hard, and macroeconomic instability also took its toll; the banks' new systemic character, while expanding loan potential, also showed its capacity for contagious liquidity crises. These gave rise, after many bank failures, to the acceptance by the central bank of lender-of-last-resort responsibilities. This marks a shift of the source of liquidity from private resources-each bank's own operations, leading banks' enlightened self-interest, and the liquidity potential of the money market-to a central institution, and the rationale for providing liquidity shifts to maintaining systemic stability, rather than the survival of individual banks.

The next element of the story is a familiar theme in American literature over the last decade or two: the moral hazard inherent in measures adopted to prevent contagion. As the banks felt safer from liquidity crises caused by their own actions or by others in the industry, they realized that the penalty for over-lending had been reduced again; once again, the limits to lending were expanded in a way that could be tested by experience.

The asset side of banks' balance sheets reflect this new confidence after World War II. They began with the war inheritance of a high proportion of liquid government assets in their portfolios and gradually ran them down in favor of higher-yielding loans. Reserves also have been steadily reduced-this is true of every EU country except Spain and Portugal, but Britain represents the extreme; in Britain reserves are now regarded as having no prudential role at all and are pared to an operational minimum, almost certainly inadequate to deal with any major shock.

The final stage of increasing financial fragility was the development of liability management, in which banks made loans in the clear expectation of having to compete for deposits to balance their books and restore such minimal liquidity as was felt necessary. By this means the source of liquidity shifts back into the hands of the banks to some extent.

The development of securitized lending works in the opposite direction: this shift to marketable loans, though still small, represents an increase in the liquidity of banks' balance sheets. Similarly, off-balance-sheet activity not only helps banks evade restrictions, but also generates income without the hazard of taking positions. These developments may be read as evidence that the liquidity cushion, systemati- 
cally reduced over the years by learning, innovating, co-opting the regulator, and taking increasing risks, had become too thin for comfort.

\section{Banks, Securities Markets, and Investment: Conclusion}

The Keynes story, that investment causes saving, depends for its validity on some fraction of any new, higher level of investment being financed by the banks, because of their ability to finance in excess of saving. There are problems for this theory inherent in new banking practice and with the evolution of the financing habits of firms. The amount of investment financed by banks was probably always small, but it is probably shrinking. The conclusion, however, is not to return to loanable funds theory, but to discover what the banks are financing: consumer loans, property deals, takeovers, and other speculative financial transactions. These are the new autonomous expenditures, the elements that shift the economy, and these factors are not only capricious, they do nothing to improve the capacity to produce and to compete. The system described in The General Theory, with all its threatening emphasis on uncertainty and instability, is a picnic by comparison.

\section{Notes}

1. Moore [1991] denies this possibility, arguing that money is never in excess supply, because it will quickly find its way to those with overdrafts who will repay them. This was also the argument of Kaldor and Trevithick [1981]. This is certainly one disposition of excess money, but there are others, viz. spending it on goods or on securities. (The last of these constitutes funding if and only if firms are simultaneously issuing the appropriate securities, otherwise the price of existing securities will be bid up without any new money going to firms.)

The argument of Moore, Kaldor, and Trevithick is merely extreme, precluding other legitimate possibilities. Moore wrongly attributes to me an equally extreme position, namely, that extinction of overdrafts is never possible. See Goodhart [1989] and Howells [1997] for most welcome refutations.

2. I reserve judgment on Keynes's stylized fact pending research on this matter for the interwar period.

\section{References}

Chick, V. Macroeconomics After Keynes: A Reconsideration of the General Theory. Cambridge, Mass.: MIT Press, 1983.

. "Monetary Increases and their Consequences: Streams, Backwaters and Floods." In Demand, Equilibrium and Trade: Essays in Honour of Ivor F. Pearce, edited by A. Ingham and A. M. Ulph, 237-250. London: Macmillan, 1984. Reprinted in Chick 1992.

. "The Evolution of the Banking System and the Theory of Saving, Investment and Interest." Economies et societes, Cahiers de l'ISMEA, Serie "Monnaie et Production." No. 3, 1986, 111-26. Reprinted in Chick 1992. 
. On Money, Method and Keynes: Selected Essays by Victoria Chick, edited by P. Arestis and S.C. Dow. New York: Macmillan/ St Martin's Press, 1992.

. "Sources of Finance, Recent Changes in Bank Behaviour and the Theory of Investment and Interest." In Money and Banking: Issues for the 21st Century, edited by P. Arestis, 55-74. Revised ed. London: Macmillan, 1993. First published in Contemporary Issues in Money and Banking, edited by P. Arestis. London: Macmillan, 1988, 30-48.

Chick, V., and Dow, S. C. "Financial Integration in Europe and Economic Growth: A Post Keynesian Perspective." Yearbook of the Vienna Institute (1997).

Crick, W. F. "The Genesis of Bank Deposits." Economica (1927).

Davidson, P. Money and the Real World. 1972. Reprint. London: Macmillan, 1979.

. "Finance, Funding, Saving and Investment." Journal of Post Keynesian Economics (Fall 1986). Reprinted in The Collected Writings of P. Davidson, edited by L. Davidson. London: Macmillan, 1990.

Dow, S. C., and P. Earl. Money Matters. Martin Robertson, 1982.

Goodhart. "Has Moore Become too Horizontal?" Journal of Post Keynesian Economics 12, no. 1 (1989): 29-34.

Howells, P. G. A. "The Demand for Endogenous Money: A Rejoinder." Journal of Post Keynesian Economics (1997).

Kaldor, N., and J. A. Trevithick. "A Keynesian Perspective on Money." Lloyds Bank Review no. 139 (1981): 1-19.

Keynes, J. M. The General Theory of Employment, Interest, and Money, The Collected Writings of John Maynard Keynes, vol. 7. London: Macmillan, 1936.

"Alternative Theories of the Rate of Interest." Economic Journal 47 (1937a). In The Collected Writings of John Maynard Keynes, vol. 14 (The General Theory and After. Part II: Defence and Development). London: Macmillan, 201-215.

. "The'Ex-Ante' Theory of the Rate of Interest." Economic Journal 47 (1937b). In The Collected Writings of John Maynard Keynes, vol. 14, 215-23.

. "D.H. Robertson on 'Mr. Keynes and Finance'; a Comment." Economic Journal 48 (1938). In The Collected Writings of John Maynard Keynes, vol. 14, 229-33.

. "The Process of Capital Formation." Economic Joumal 49 (1939). In The Collected Writings of John Maynard Keynes, vol. 14, 278-85.

Minsky, H. P. John Maynard Keynes. New York: Columbia University Press, 1972.

Moore, B. J. "Has the Demand for Money been Mislaid? A Reply to 'Has Moore Become too Horizontal?'" Journal of Post Keynesian Economics 14 (Fall 1991): 125-33.

Studart, R. Investment Finance in Economic Development. London: Routledge, 1995.

Toporowski, J. "Corporate Liquidity, Capital Markets and their Valuation." Economie Appliquee. 46, no. 3 (1994): 65-84.

Wray, L. R. "The Political Economy of the Current U. S. Financial Crisis." International Papers in Political Economy 1, no. 3 (1994): 1-51. 